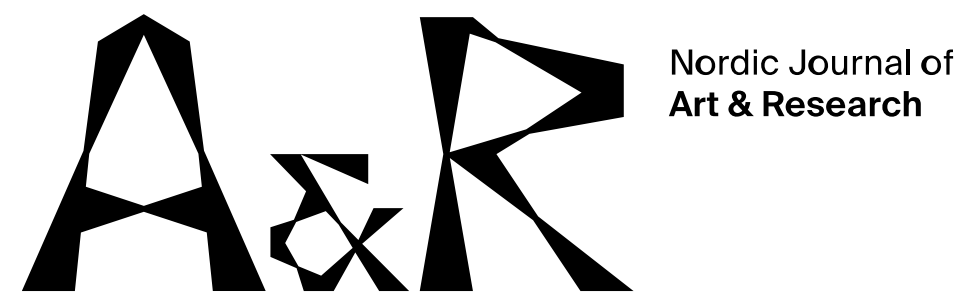

ISSN: $1893-2479$

Volume 10, $\mathrm{Nr} 3(2021)$

https://doi.org/10.7577/information.4661

\title{
Artistic research in processes of urban change
}

\author{
Charlotte Blanche Myrvold ${ }^{1}$ \\ Kulturtanken - Art for Young Audiences Norway
}

\begin{abstract}
Can the figure of the city of knowledge be an inspiration to commissioning of artistic research in contexts of urban change? This article argues that it represents a way beyond the seemingly dead ends that have been forged by the temporary and creative city. This article presents some initial reflections on this subject and reflects upon how artistic research expands the roles ascribed to public art.

The conceptual approach to understand the relations between knowledge and the development of cities applied in this article, draws on the idea that cities are learned developed by urban geographer Colin MacFarlane (MacFarlane, 2011). The article applies MacFarlane's concept to artistic research in public space and argues that artistic research as public art can move divisions between what is extra-public and public, known and unknown. Drawing on public art projects that have relations to the urban development of Bjørvika, the article argues that artistic research of the city produces new ways to "learn the city" and conceive change.
\end{abstract}

Keywords: Public art, urban development, city development, artistic research

${ }^{1}$ charlotteblanche@hotmail.com, cbm@kulturtanken.no 


\section{Artistic research in processes of urban change}

The walls of Fredrikke, the cafeteria at the University of Oslo, are decorated with murals. When I was a student there, mealtimes were framed by paintings of gigantic bookshelves. I remember Karl Marx's Kapitalen leaning dynamically against other pillars of Western thought. The over-sized books were projected with a symbolic perspective that conveyed their importance in the ecosystem of the university. Returning to the cafeteria years later, I was surprised to see that the bookshelves were gone. Instead, a mural of the city of Oslo covered the walls. The new painting presents a map of activities in public spaces, such as tai chi, cycling and skateboarding. Books no longer figure in this new picture, which seems to rebrand both the university and knowledge in general. Instead of ivory towers, here the contemporary knowledge society is represented by urban space.

I was intrigued by this change, because the new theme, the city, touched on my inquiries into urban change and public art. In the mural, I recognized the model city as it was rendered in policy documents. Active is a key word, but there was something more here: a DIY city spread across the walls with people demonstrating their skills in public space. In me it invoked a question about the relations of such a figure of a city of knowledge and the practices of public art.

The mural illustrates a seductive discourse and was for me a reminder that the two main discourses on cities that I have been studying, namely the creative city and temporary city, need to be revised in perspective of the role artistic knowledge is, and has been, playing in processes of urban change. This article presents some initial reflections on this subject and reflects upon how artistic research trangresses the roles ascribed to public art. The conceptual approach to understand the relations between knowledge and the development of cities applied in this article, draws on the idea that cities are learned developed by urban geographer Colin MacFarlane (MacFarlane, 2011). The article applies MacFarlane's concept to artistic research in public space.

\section{Figures of urbanity and the role of art}

The transformation of the waterfront area of Bjørvika in Oslo, which began in 2003, was strongly influenced by the notion of the 'creative city' and the cultural economy. The creative city basically pivots around the potential of using cultural capital to boost the economy in a logic of inter-city competitiveness (Florida, 2012; Landry, 2008). Although problematic in many ways, when applied in urban development, cultural strategies ascribe roles to art, thereby producing positions within a development scheme to protest and contest these very same roles. Another figure of urbanity that ascribes a role and forges an action space for art is 'the temporary city'. This model 
takes city life as its object, distributing temporary activities to changing locations in an attempt to influence the movement of people in the city (Bishop \& Williams, 2012). The "Car-free city life" programme of the municipality of Oslo is an example of an approach that draws on temporariness by facilitating transient art events in the city's public spaces.

Knowledge, or learning, as an optic to understand and develop cities, holds a yet unexploited potential to formulate the roles of art in the city. The ambition of grasping a city from the point of view of knowledge entails the recognition of a plurality of forms of knowledge. In this mix, technology and artificial intelligence are often highlighted. But it represents a framework for discussing artistic research as a form of public art. Urban development is a pluralistic process involving multiple forms of professional knowledge, different sets of methods, and ways of learning.

Interestingly, urban development is increasingly becoming a context in which art is commissioned. The Bjørvika development prioritized temporary forms of public art during the construction process, and this practice is being continued in the next large development project in Oslo, Hovinbyen. Also, Public Art Norway has launched a programme for art in urban development. As artists are being invited into the pluralistic blend of competences that urban development represents, it is timely to imagine roles for public art that go beyond the discourses on the temporary and creative city. The matter is relevant because the role and space of action of art in urban development change according to which vision of urbanity urban developers aspire to realize.

\section{Learning the city}

The term public art can denote a range of different relations in which art comes into contact with a public realm, for instance public ownership or public accessibility. When urban development is the backdrop, a relevant definition of public art is 'art in the public's interest' (Raven, 1993; Cartiere \& Willis, 2008). The reason is that when art operates in contexts of urban development it interacts with processes of change that are framed as in the public's interest. However, these processes are seldom accessible to a wide public and artistic investigations can unfold in a border zone of what is in public and extra-public (Kester, 2013). The question of publicness remains crucial even so, because societal conceptions of publicness initiate and drive urban changes. What the public's interest is, and what is public are issues that remain contested and require situated engagement.

Learning the City is the title of a book by urban geographer Colin MacFarlane. Here, MacFarlane states that although urbanism is obsessed with knowing the city, the question of how we acquire that knowledge is overlooked. His study traces the unequal mobilities of forms of knowledge and the dominance of some forms over 
others (MacFarlane, 2011, p. 28). Not only does he argue that urbanism demands learning, more specifically, he discusses how it can be relearned and give rise to more democratic and sustainable approaches. One focus of his study is informal ways of "learning the city", and in this respect he sets up embodied and situated learning as an alternative to globally distributed knowledge and top-down approaches. "Potential," MacFarlane writes, "signals the relation between the actual and the possible in learning - between the city that is known and the city that might be or could have been" (2011, p. 25). MacFarlane's theory on critical urban learning formulates relations between learning and change. By learning the city, one can, as MacFarlane suggests, create new trajectories between history and potentiality, the actual and the possible, because new knowledge about the actual renders visible formerly unknown possibilities. MacFarlane's theoretical framework provides a possibility to investigate new aspects of the relation between learning and cities, and I apply it to understand artistic research as a way to relearn the city by tracing trajectories between the actual and the possible, and thereby reinvestigating the possibilities and potentials connected to what is hold as public.

\section{Public spaces for artistic knowledge}

Let's take one last glance at the mural in the university cafeteria. The movement from library to urban space resonates with the trajectory of contemporary art that curator Claire Doherty has elegantly characterised as 'from studio to situation' (Doherty, 2004). Contemporary art production is moving from the confined spaces of the atelier straight into public spaces. Creation and reception of art coincide in post-studio practices. Artist Susan Lacy points out succinctly that the question of artistic skill is essential to understanding community-based art practices where the relation to the audience feeds directly into the artistic process (Lacy, 1995). Listening and empathic identifications are among the skills that Lacy accentuates, yet it is also worth noting that these skills are trained and performed in the city, not in the studio. For the philosopher Rancière, the very notion of production denotes a shift in the relation between making and viewing art by rendering processes of fabrication visible (2000, p. 71). Rancière's point is to draw attention to changes in the distribution of the sensible. In post-studio art practices, making and seeing are joined in both time and space.

These post-studio practices have significant consequences for the kind of art forms that are accessible in the city. However, we should also consider how they open public spaces by giving a public dimension to forgotten or supressed dimensions of the city. Artistic methods, skills and research enter the artworks' public life in a new way. The Artistic Turn: A manifesto traces the trajectory of artistic research from private studios to the institutional framework of higher education. 
Art as 'commodified' through its duplication and consumption has already become part of market knowledge, while artistic skills and knowledge have generally remained hidden, accessible only by an educational trajectory and exchanges between insiders. The recent move towards the institutionalisation of research by artists in artistic milieus and education is another way of opening the doors of performance-related 'know-how'. This contributes another multi-faced aspect to the field: artistic skills - concerning personal artistic trajectories and their interrelatedness with science and other forms of knowledge. (Coessens, Crispin \& Douglas 2009, p. 22)

From being the hidden aspect of an artistic practice, in the research programmes of higher education artistic research has gained a public dimension in its own right. The manifesto points forward and asks what roles artistic research can play outside educational institutions. In looking at artistic knowledge as an aspect of the societal function of art, artistic research presents itself as a possible expansion of what we understand as public art.

\section{Art as a vantage point for contemplating change}

"Farewell video store, farewell tobacco store, farewell payazzo, farewell halvorsens konditori, farewell hot dog stand, welcome espresso house"

"Farewell Plata, welcome construction site, welcome supercharger, welcome fjord city"

"Farewell existential puberty thoughts, farewell biological clock, farewell six pack, farewell libido, farewell to the idea of infinite growth"

These quotes are taken from Dries Verhoeven's intervention, Fare Thee Well (2018), during the Oslo International Theatre Festival. The work comprised four telescopes placed in a room in the Radisson Plaza Hotel, all directed at a single spot in the city. Sitting down and gazing through the devices, viewers could see an LED sign on a façade on the lower slopes of Ekebergåsen. Looking through the circular eyepiece, multiple farewells and welcomes passed before the viewer's eye, strung together as a moving text on a wall. The magnified text assembled a series of urban changes of existential, political and physical character, reintroducing them into the city as floating words. A city which, incidentally, was turned upside down by the wonders of the telescope. What is urban development if not a process that turns the city upside down? What is urban development if not change? For 14 minutes the viewer was presented with a series of changes, urban phenomena disappearing and appearing in the city. The totality of changes added by Verhoeven reached beyond each singular transformative event and created a representation of urban change per se. 
However, the distant viewpoint and the fatalistic form of these final farewells presented change as an irrevocable chain of events out of reach of the influence of the individual.

Fjord City is among the changes that the Fare Thee Well welcomed. Fjord City is the name, or the image, carefully constructed to brand Oslo's waterfront development, which encompasses the Bjørvika area. Even so, not only the fjord, but also culture has played a crucial role in the planning and transformation of the area. The development plan of 2003 was passed with an appendix formulating a series of recommendations concerning the role and use of areas for culture, with direct consequences for the role and space of action of public art in the transformation process. Art in public spaces was encompassed within a larger culture-led development strategy that aimed at activating the area, forming a local identity, and creating ownership (Eeg-Tverbakk et.al., 2009). Moreover, the public-private partnership model applied meant that the public art programme was financially and structurally linked to the private company Bjørvika Utvikling AS (BU). The conflation of public and private interests had impacts on both the reception of art and the strategies developed by artists working in the area. Artist Marianne Heier's response to a commission she received from BU in 2005 illustrates very well the concerns of the art field. Was art being used as a mean to construct a 'cultural image' of the area representing thus a relatively cheap investment meant to boost the real estate market? Heier took it upon herself to develop a Robin Hood strategy, and thus redirect the investment in Bjørvika's public art programme to the whole city. However, when her original idea of reopening the Sagene public baths proved impossible, she presented instead a series of photos of deserted suburban swimming pools, redirecting attention, instead of actual money, to other parts of Oslo. Her project $A$ Drop in the Ocean confronted the constructed image with local and empirical knowledge about the city, in this case, the inaccessibility of swimming pools and the poor swimming skills of kids from Oslo.

\section{Changes in representation}

Heier uses her art to capture a fundamental dilemma concerning the association between art and image building. The ambiguous role of art has also been addressed by researchers studying the area of transformation. Heidi Bergsli, Jonny Aspen and John Pløger, for example, have addressed the danger posed by translating art's critical potential into an image designed for consumption (Bergsli, 2015; Aspen \& Pløger, 2015).

Nevertheless, a discussion of urban development that limits it to a process of the commodification of cultural capital is reductionist with regard to the roles art can play in such contexts. In this sense, the creative city is not only a framework with 
conditions for the commissioning of art, it is also an optic that researchers and artists can explore in their approaches. It is likely that another perspective, for instance that of a city of knowledge, will lead us to observe other aspects of an art intervention. Is it possible to redirect attention from the commodification of art as product to the agency of artistic competence? Heier's public display of empirical and situated forms of knowledge exposes the simplified image of the Fjord city as wrong and unsubstantiated, and can be understood as a epistemological critique (Myrvold, 2017). This matter because representations are more than sales gimmicks; they are tools to administrate change.

The role of visual representation in defining public culture is a central concern in urban sociologist Sharon Zukin's writings on the symbolic economy's influence on cities (Zukin, 1995; 1996). Zukin rightly points out that visual representations of cities have social and economic consequences, because representations have the ability "to control urban spaces by 'framing' a vision" (Zukin, 1996, p. 241).

Visual representations of space define which dimensions of a place will circulate in public and influence the public life of places by addressing and attracting particular publics. In the construction of place images, urban scholar Graeme Evans identifies a conflict between place marketing and democratic city management (Evans, 2006). Since branding seeks to construct unified versions of place identity, it ultimately enters into conflict with democratic interests and methodological approaches that deal with the complexity and diversified subjectivity of city ownership (Graeme, 2006, p. 202). The complexity of social life is simplified and excluded from coherently designed representations of urban life. By contesting the image of place, Heier's project also circulated alternative forms of site knowledge and represented public interests omitted from the marketing image.

\section{Changes in site narratives}

Although artists might have been invited into the development of Bjørvika for the 'wrong' reasons, the cultural development represents a framework that commissions artists to do temporary projects during the construction phase. It provides a position for artists to interact with a process of change. In Fare Thee Well the audience could experience change from an elevated and distant vantage point. It reminded me of Michel de Certeau's description of a view of Manhattan from the $110^{\text {th }}$ floor of the World Trade Centre. This way of looking at the city from above, de Certeau argues, represents a viewing practice that places the world at a distance and enables us to possess it in one gaze (de Certeau, 1990). The distance, he suggests, translates the matter of the city into a concept, however it does not allow us to know the city as matter (de Certeau 1990, p. 142). De Certeau questions this form of visual knowledge that keeps messy urban reality at a distance. The artist collective 
Futurefarmers steps into the messy processes of Fjord City. Here as well change is essential, although the project is not about representing change, but rather about entering and influencing processes of urban change from a situated position within the development.

Futurefarmers were commissioned by the BU public art programme in 2011. Today, their project has the form of an urban farm and a bakehouse and goes under the name of Losæter. But to comprehend the role of this art project in the area transformation, it is necessary to look at how it has influenced the planning of the site. Losæter and the bakehouse are constructed on the site of Loallmenningen, one of the seven public spaces comprised in Gehl and SLA Architects' public space programme for the area. Launched in 2008 , the design concept for Loallmenningen projected the site as an area for recreational sports activities. The envisaged facilities included a football pitch and a climbing wall.

At the time when Futurefarmers were commissioned, the construction of Loallmenningen was scheduled for 2017 and the site was at the periphery of the development. The artists intervened on this site regularly from 2012, and together with the allotment gardens installed by $\mathrm{BU}$, they inscribed urban farming as a practice there. In 2013 they hosted a month-long programme of events and workshops on the site and built a temporary bakehouse. But the temporary events pointed forward. Engaged by BU to do a permanent project in public space, Futurefarmers' temporary interventions evolved into a permanent on-site structure to which the participating public contributed. Thus, the events, and in particular the temporary bakehouse of 2013, did not remain an isolated art project in a transient present, but were framed instead as artistic research for a future bakehouse.

Futurefarmers' Losæter, or the Flatbread Society as the project is also called, deviates from the original concept for the site. One significant aspect of the project is the assertion of green, ecological values. Futurefarmers has rehabilitated the soil of the site, cultivates heritage grains and promotes a DIY urban farming culture. Together with Even Smith Wergeland, I have suggested that the project represents a move from the ethos of cultural planning, and that the artistic constellation of public participation and green values respond to a contemporary green shift in urbanism and the vision of an active city (Myrvold \& Wergeland, 2016). Yet this does not imply an abject artistic surrender to the changing tides and trends of urbanism. Rather we suggest that the conflation of interests between planning and art when it comes to public participation and green values, opens a space from which Futurefarmers can manoeuver and influence the decision-making processes regarding Loallmenningen. Essential to the artists' approach is to shift attention from the fjord to the soil. 
The green shift that Futurefarmers have orchestrated at Loallmenningen is a change of the narrative of the site, from fjord to farming, and from sports to baking. Similar to a place image, a site narrative is a tool to edit the complexity of place. It is a notion that I borrow from urban theorist Robert Beauregard. According to him, a site narrative is a strategy that professional developers use to structure the complexity of a site and overcome ambiguities in discourse (Beauregard, 2005). A site that is perceived as empty - of history and of personal embedded narratives - is more attractive for development because it can accommodate new narratives. The act of restructuring site narratives is in Beauregard's words a discursive displacement (2005, p. 54).

The difference between a site narrative and a place image is that a place image is a branding tool and as such reflects the methods and characteristic skills of the marketers. The site narrative, on the other hand, is constructed from and negotiated between various elements of knowledge about the site, mainly acquired from professional contributors such as architects, archaeologists, investors and bureaucrats (Beauregard 2005, p. 55). In being a negotiation of different forms of competence and different ways of learning the city, the site narrative represents a locus to negotiate change. The project of Futurefarmers shows that also artistic competence and research methods play a role in the negotiation of a site narrative.

In the case of Bjørvika, landscape architect Lisa Diedrich pointed out that the fjord is the main protagonist in both the authoritative planning and development narrative and the individual design narrative for the public spaces developed by Gehl and SLA landscape architects (Diedrich, 2013). The outcome of these processes is a homogeneous narrative that has discarded the social, historical and industrial character of the area prior to redevelopment. It is noteworthy that in Bjørvika the place image and the site narrative are so similar. In other words, when Futurefarmers entered the area, many layers of site knowledge were omitted from the discourse. The discursive displacement Bjørvika was undergoing a move from a story about the productivity of the industrial port and modern highway, to a story about recreation and productivity through culture and nature assets. Within the artistic framework set in place by Futurefarmers at Loallmenningen, a new discursive displacement was set in motion, demonstrating other potentials of the site.

\section{Public art as artistic research}

The temporary bakehouse put in place by Futurefarmers in 2013 performed a double function. On the one hand, it was a public artwork plus a programme of participatory events in Bjørvika that opened and activated the site for visitors. The workshops had different themes and activities, such as oven-building, bread-baking, soil-testing and the planting of heritage grains. On the other hand, it was a research framework set in 
place by the artists - all foreigners and strangers to the city - to gather knowledge about the site. Amy Franceschini, a San Francisco based artist and the front figure of Futurefarmers, explained their approach unfolding from the questions of Who is Bjørvika?" and "What does Bjørvika need?" (Myrvold 2016, p. 7). The question of who Bjørvika is represents more than the mere curiosity of artists coming in from abroad. As in research in general, in artistic research the questions one poses give a direction to the inquiry.

Equally interesting as the research question, is the methods applied to learn the city and negotiate the site narrative. The relational approach to site was conducted around the object of flatbread. Flatbread is a traditional type of Norwegian bread, but as the artists discovered when visiting the multicultural area of Grønland, it is a traditional and much-loved type of food in many cultures. In 2013 Futurefarmers visited various locations in Oslo with a mobile oven, which gave an opportunity for baking and sharing flatbreads, and gathering conversations and stories. As a transcultural phenomenon, flatbread carried a set of cultural and practical connotations that elicited personal experiences from a number of people. As a protagonist in the new site narrative, it formed a more multilingual platform for storytelling than the fjord.

By constructing relations around the multiple meetings centred on flatbread, this method of learning the city is similar to a specific form of critical urban learning outlined by MacFarlane. By following a material object in different urban contexts, one is able to render visible some of the city's social, cultural and economic differences (MacFarlane 2011, p. 161). However, an artistic approach to learning the city differs from the one outlined by MacFarlane in a significant way. The artists welcomed and played with imaginative, absurd and outlandish interpretations of flatbread and thereby superimposed practical, relational and imagined uses of the flatbread. By introducing imagination and play into the process of learning the city, the trajectories that are formed between the actual and the possible are multiplied.

One should not neglect the efficiency of the programme of participatory events that Futurefarmers hosted in Bjørvika. Bringing people together, activating the area and creating city life have all been outlined as explicit ambitions for the Bjørvika development (Doherty, 2011; Plan- og Bygningsetaten et al., 2003; Gehl et al., 2007). The adoption of a participatory and event-based approach has convincingly illustrated that the change in narrative is a sustainable approach to the objective of populating the public space of Loallmenningen. The aforementioned double structure of the temporary event, involving both research and a public venue, has provided both a mean to learn the city and a public display of audience participation. The latter should not be neglected as a means to negotiate the site narrative. 
The public dimension of the artistic research provided a stage to the lived, imaginative and political aspects of site. It is characteristic of research to discover something yet unknown, and putting it forward to be seen, articulated and hold in common. Art theorist Grant Kester's notion of extra-public dimension of participatory art, can be useful for a further framing of the relations between artistic research and processes of change in the city (Kester, 2013). However, while Kester emphasizes that that art can have important dimensions that are not made publicly accessible, I believe artistic research to be an opposite movement where significant forms of knowledge are given a body and extracted from the extra-public, areas that are outside the public realm, and made public.

\section{Artistic research of the city}

What use can we extract from this retrospective gaze upon the development of Bjørvika? This article has described ways in which public art participates in a web of site narratives and place images, and suggests that it forms ways in which we learn the city and forms bridges between the city that is known and the city that might be. The article's main purposes are to mark the potential role of artistic research in contexts of urban development, and to suggest ways in which artistic knowledge transgress the spaces circumscribed for art in the discourses and commissioning strategies of the creative and temporary city.

But timing is crucial. Beauregard frames constructions of site narratives to a moment prior to the implementation of change, when he writes: "Narratives are constructed and deconstructed prior to but in harmony with the physical transformation eventually to be realized" (2005, p. 55). The temporary and participatory character of Futurefarmers' event suited the underlying ambition to activate the area and opened the door to the site during an early phase of the development. The timing enabled an intervention not only on the construction site, but also in the site narrative that was still being formed. Thereby the intervention went beyond fulfilling the role cast for art in the vision of the temporary 'active' city and produced new ways to learn the city and conceive change.

Andrea Phillips rightly points out that artistic research is inherent in all site-specific approaches (Phillips in Petersson and Sandström, 2015). Yet research as such is only rarely commissioned. Can the figure of the city of knowledge be an inspiration to commissioning of artistic research in contexts of urban change? It seems a relevant way out of the seemingly dead ends that have been forged by the temporary and creative city. While the discourse of the creative city held art in public spaces the hostage of strategic image building, the vision of the temporary city reduces it to a bait in the continuous attempts to activate urban areas and draw people to specific locations for commercial reasons. 
Artistic research of the city represents a potential way of working in public which, while not immune to the abovementioned misuse, opens up other sets of relations between the city and art. Ultimately, poverty in methodological approaches leads to the reproduction of stereotypes. Not least, stereotypes about publicness and the public's interest. Artistic research in public spaces can counteract these mechanisms and as well as reinscribe divisions between what is extra-public and public, known and unknown.

\section{About the author}

Charlotte Blanche Myrvold works in Research \& Development at Kulturtanken - Art for Young Audiences Norway. She holds a Ph.D. from Oslo School of Architecture and Design and wrote the thesis Public Art. Urban Learning on the subject of public art and urban development. She has worked at Oslo National Academy of the Arts and OsloMet - Oslo Metropolitan University. She is the co-editor of the anthology Kunstformidling. Fra verk til betrakter (2019).

\section{References}

Aspen, J. \& Pløger, J. (2015). Den vitale byen. Scandinavian Academic Press.

Beauregard, R. A. (2005). From Place to Site: Negotiating Narrative Complexity. In C. J. Burns \& A. Kahn (Eds.) Site Matters. Design Concepts, Histories, and Strategies, (p. 39-58). Routledge.

Bergsli, H. (2015). Urban attractiveness and competitive policies in Oslo and Marseille. The waterfront as object of restructuring, culture-led redevelopment and negotiation processes/ [Ph.D., University of Oslo.]

Bishop, P., \& William, L. (2012). The Temporary City. Routledge.

Cartiere, C., \& Willis, S. (2008). The Practice of Public Art. Routledge.

de Certeau, M. (1990). L'invention du quotidien: 1. arts de faire. (Original edition, 1980.) Gallimard.

Coessens, K., Crispin, D. \& Douglas, A. (2009). "The Artistic Turn: A Manifesto." OpenAIR@RGU. Accessed 12.08.2016 at http://openair.rgu.ac.uk

Diedrich, L. (2013). Translating Harbourscapes. Site-specific Design Approaches in Contemporary European Harbour Transformation/ [Phd diss. University of Copenhagen]. 
Charlotte Blanche Myrvold. Artistic research in processes of urban change

Doherty, C. (2004). Contemporary Art: From Studio to Situation. Black Dog Publ.

Doherty, C. (2011). Slow Space: A Curatorial Vision for Bjørvika. Bjørvika Utvikling.

Eeg-Tverbakk, P. G., Grønning, M., Hansen, T., Hovind, A. B. \& Staal Brekke, T. (2009). Temahefte Kunst. Bjørvika Utvikling.

Evans, G. (2006). Branding the City of Culture. The Death of City Planning? In J. Monclus \& M. Guardia, (Eds. ) Culture, Urbanism and Planning, (p. 197-214). Ashgate.

Florida, R. (2012). The Rise of the Creative Class: Revisited. Basic Books.

Gehl Architects, SLA Architects, Bjørbekk \& Linheim AS, and Hansen \& Henneberg. (2007). Temahefte for byrum og gaterum. Bjørvika Infrastruktur AS.

Kester, G. H. (2013). Conversation Pieces: Community and Communication in Modern Art. University of California Press.

Lacy, S. (ed.) (1995). Mapping the Terrain: New Genre Public Art. Washington Bay Press.

Landry, C. (2008). The creative city: A toolkit for urban innovators. Earthscan Comedia.

MacFarlane, C. (2011). Learning the City: Knowledge and Translocal Assemblage. Wiley-Blackwell.

Myrvold, C. B. (2017). Public Art: Urban Learning/PPh.D. diss. The Oslo School of Architecture and Design].

Myrvold, C. B. (2016). Flatbread Society and the Discourse on Soil. The International Journal of Social, Political and Community Agendas in the Arts, 11 (3),1-21.

Myrvold, C. B. (2013). Negotiating the Image of the City: A Discussion of Skilled Perception and the Role of the Artist in the Redevelopment of Bjørvika. InFormation, $2(2), 124-144$.

Myrvold, C. B., \& Wergeland, E. S. (2016). Participatory action in the age of green urbanism: How Futurefarmers leapfrogged the culture consumer? International Journal of Cultural Policy, 24 (3),1-19. 
Charlotte Blanche Myrvold. Artistic research in processes of urban change

Petersson, F. J., \& Sandström, F. (2015). Akademin och Offentligheten. Kunstkritikk. 04.11.2015. Accessed 11.08.2016 at http://www.kunstkritikk.no/artikler/forskningenoch-offentligheten/

Plan- og Bygningsetaten, Oslo Havnevesen, Eiendoms- og byfornyelsesetaten, Statens vegvesen region øst, Statsbygg, and ROM Eiendomsutvikling AS. 2003. Bærekraft i Bjørvika: Kulturoppfølgingsprogram.

Rancière, J. (2000). Le partage du sensible: Esthétique et politique. La Fabrique.

Zukin, S. (1995). The Culture of Cities. Blackwell Publishers.

Zukin, S. (1996). Cultural Strategies of Economic Development and the Hegemony of Vision. In A. Merrifield and E. Swyngedouw (Eds.) The Urbanization of Injustice, (p.223-243). Lawrence \& Wishard. 